\title{
Post-rift landscape development of north-east Brazil
}

\author{
Johan M. Bonow, Peter Japsen, Paul F. Green, Peter R. Cobbold, Augusto J. Pedreira, \\ Ragnhild Lilletveit and Dario Chiossi
}

The evolution of the landscape of north-east Brazil in relation to the burial and exhumation history of both onshore and offshore areas is the focus of a research project carried out for StatoilHydro do Brasil and Petrobras from 2007 to 2009 by the Geological Survey of Denmark and Greenland in collaboration with Geotrack International. In hydrocarbon exploration it is important to understand the regional tectonic framework and thus also to consider the volumes of rocks that may have been present and then removed during the geological past. For example, the timing of hydrocarbon generation and changes in migration routes can be assessed when the timing and magnitude of uplift and erosion is known. Studies in West Greenland have demonstrated the usefulness of large-scale, low-relief, high-level landscapes as markers of uplift events, and in particular the strength of combining the denudation history from landscape analysis with the cooling history from apatite fission-track analysis (AFTA) data and the stratigraphic record (Bonow et al. 2006, 2007; Japsen et al. 2006, 2009). In the study area, there are two plateaux with elevations up to $c .1300 \mathrm{~m}$ above sea level (a.s.l.). The plateaux are currently being dissected by deeply incised fluvial valleys, and escarpments separate the two plateaux. The lowlands cut across Early Cretaceous rift systems along the Atlantic margin, including the

Fig. 1. A: Geological map of the study area (based on CPRM 2001, 2003). Precambrian basement is covered by younger sedimentary sequences, which are important age constraints for the different peneplains. RTJ, Recôncavo Tucano-Jatobá Basin. The arrow points at the small Sabiá Formation outrcrop. B: Topography of the study area. Two topographical features dominate the landscape: a lower surface, which is a plain mainly at 200-500 $\mathrm{m}$ a.s.l. (greenish and light yellow) and the higher surface which is a plain mainly at 900-1200 $\mathrm{m}$ a.s.l. (orange and reddish). Pronounced escarpments separate the two features. Elevation data source: Jarvis et al. (2008). intracontinental Recôncavo-Tucano-Jatobá (RTJ) Rift and also the Camamu Basin, of which the western margin is exposed onshore (Fig. 1). The RTJ Rift is a mature hydrocarbon province, whereas the deep-water parts of the Camamu Basin are the target of frontier exploration (e.g. Magnavita $e t$ al. 1994; Davison 1999; Cobbold et al. 2008). The post-rift sequence in the RTJ Rift and the inshore Camamu Basin is thin or absent. However, it has been estimated that up to $2000 \mathrm{~m}$ of sedimentary cover once was present, but has now been removed (Magnavita et al. 1994).

The Atlantic margin of Brazil is characterised by elevated plateaux cut by deeply incised valleys, but this landscape has a pattern common with many other passive continental margins with elevations from 1000 to $2000 \mathrm{~m}$ a.s.l. or more around the world, for example in Norway, East and West Greenland and south-east Australia. Mesozoic-Cenozoic rift systems parallel to the coast are generally present offshore

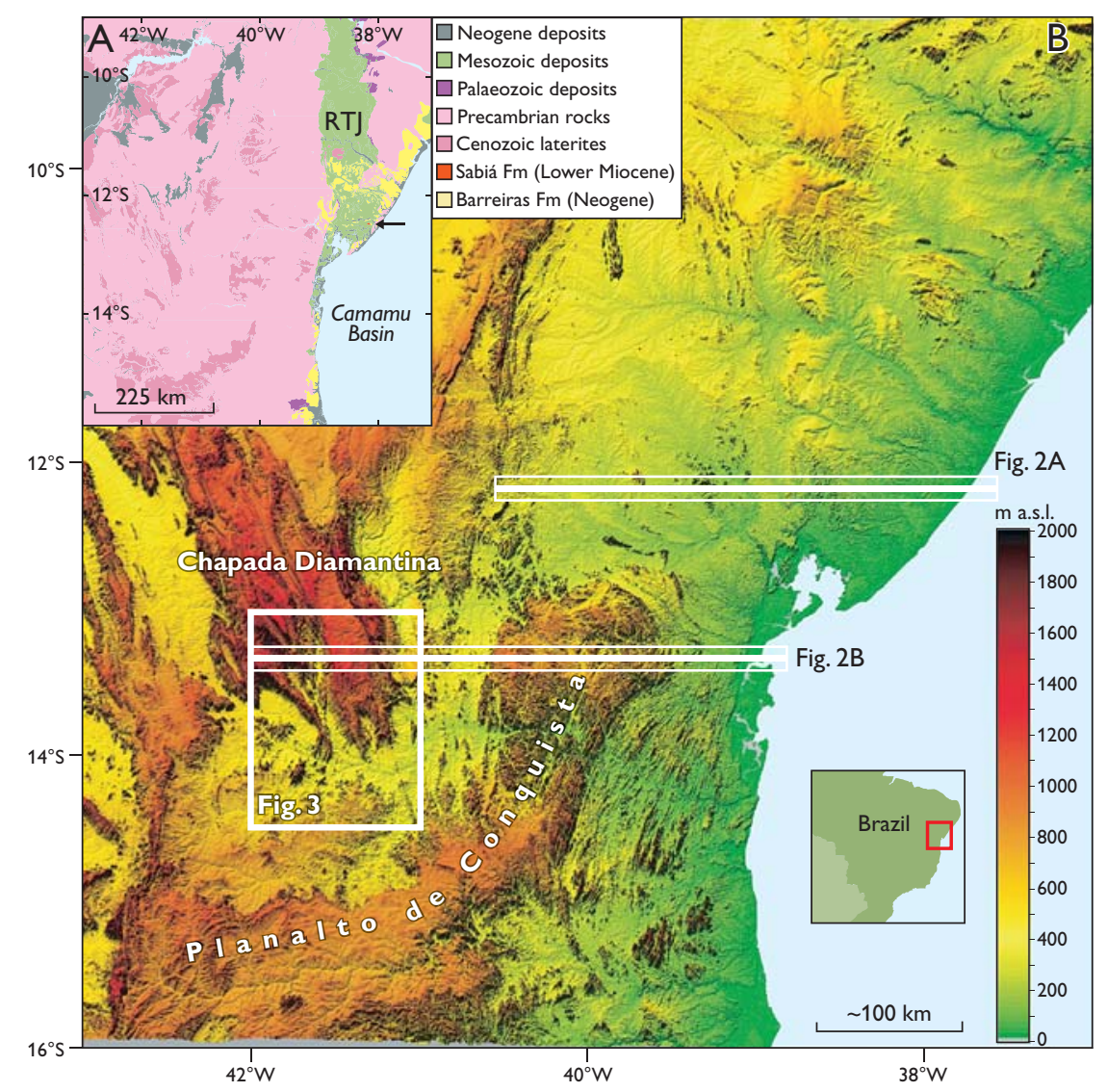




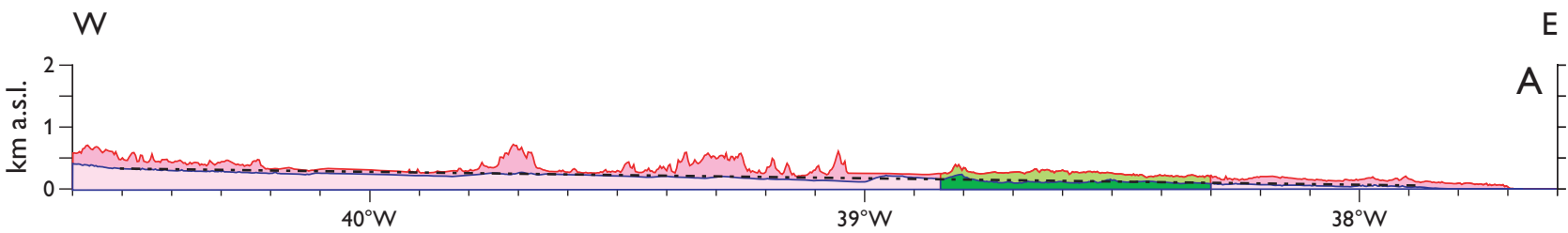

W

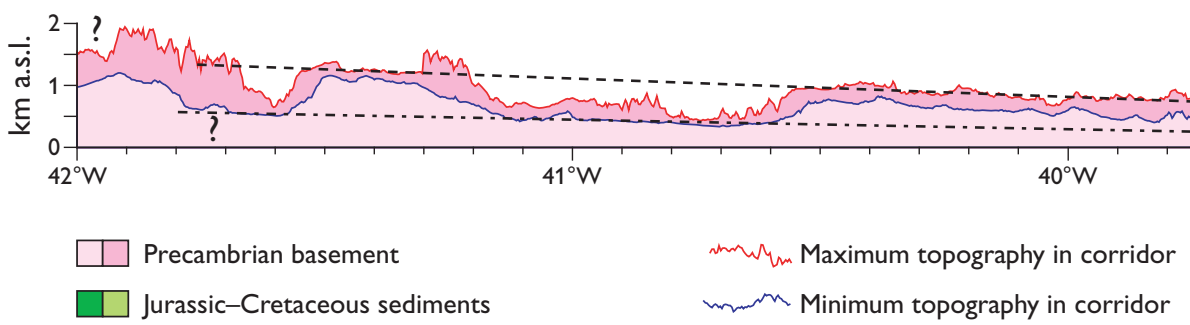

\section{.}

. 
Fig. 3. Digital terrain model with a higher surface (HS) and a lower surface (LS) that are separated by escarpments in the Chapada Diamantina area The higher surface forms a coherent plateau at 1200-1400 m a.s.l. (reddish) with only minor valley incisions. This plateau is presently being dissected by rivers along the escarpment, eroding down to the lower surface, here at 500-400 m a.s.l. (greenish). Escarpments are also found above the higher surface, maybe representing steps towards older surfaces at higher elevations. The arrow indicates the location and direction of the photograph in Fig 4. Elevation data source: Jarvis et al. (2008).

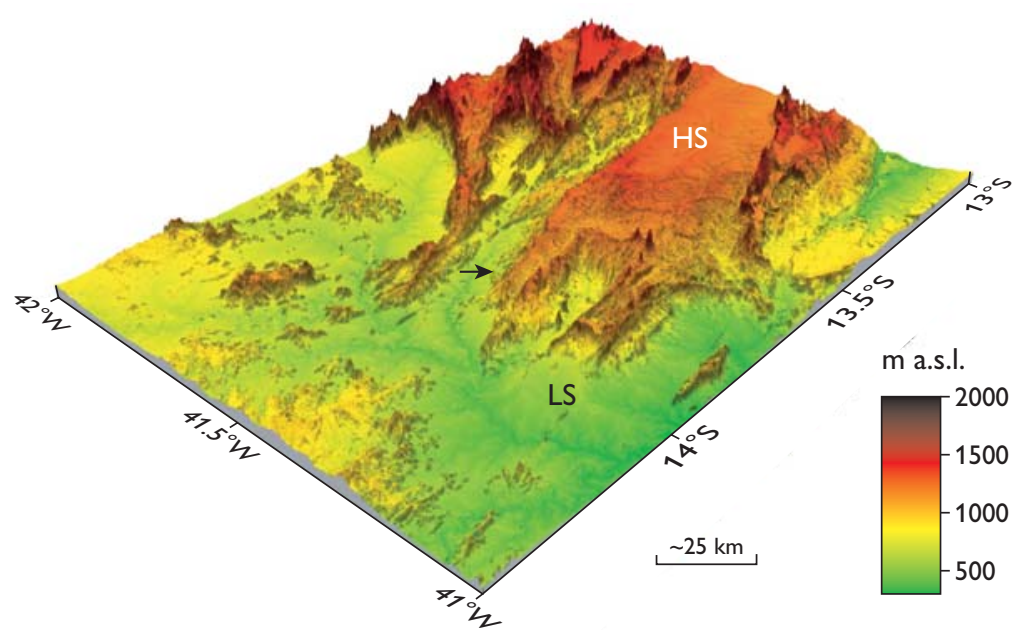

separate the lower surface from the higher surface (Figs 3, 4). In detail, these escarpments usually coincide with bedrock boundaries, thus reflecting bedrock resistance. The valley patterns and the incision of rivers in the Recôncavo and Tucano basins also show that the lower surface is rapidly being dissected by incising rivers, due to a change in baselevel after formation of the lower surface.

\section{Geological constraints}

The lower surface cuts across post-rift strata within the rift and Precambrian basement outside the rift (Figs 1, 2). The formation of the surface thus post-dates the Aptian Marizal Formation (e.g. Magnavita et al. 1994). The age of the surface may, however, be further constrained by an outlier of the early Miocene, marine Sabiá Formation within the Recôncavo Basin (Fig. 1A) where this sedimentary unit has been found in deep trenches (Viana et al. 1971). This outlier testifies to a marine transgression that occurred before the formation of the lower surface because the outlier is truncated by that surface, and thus the lower surface is younger than early Miocene.

The areas where the higher surface is defined are characterised by laterites (deep weathering profiles) of Cenozoic age (Fig. 1; CPRM 2001, 2003). Both the higher surface and the laterites are currently being destroyed by erosion along the escarpments that outline the plateaux. Consequently, the laterites must have formed at the end of the ero-

Fig. 4. The lower surface with the escarpment and the higher surface in the background. See Fig. 3 for location. sional process that shaped the higher surface. Based on the age of the laterites we can deduce that the higher surface formed during the Cenozoic.

This time interval can be further narrowed if we take into account that the younger, lower surface was formed subsequent to the deposition of the Sabiá Formation. The age of the higher surface may thus tentatively be estimated to be Palaeogene, which implies that the landscape at that time was a peneplain close to sea level. This suggestion is in agreement with observations from similar plateaux north and south of the study area where the plateau surfaces were exposed during the Palaeogene according to stratigraphic data (Sant'Anna et al. 1997; Morais Neto et al. in press) and geochronological constraints on deep weathering (Spier et al. 2006; Lima 2008). Alternatively, both the higher and the lower surface in the study area may have formed during the Neogene, which also agrees with the Cenozoic age of the laterites. Geomorphological analysis alone cannot definitely conclude which alternative is correct, but we prefer the first alternative because it is consistent with independent constraints from outside the study area.

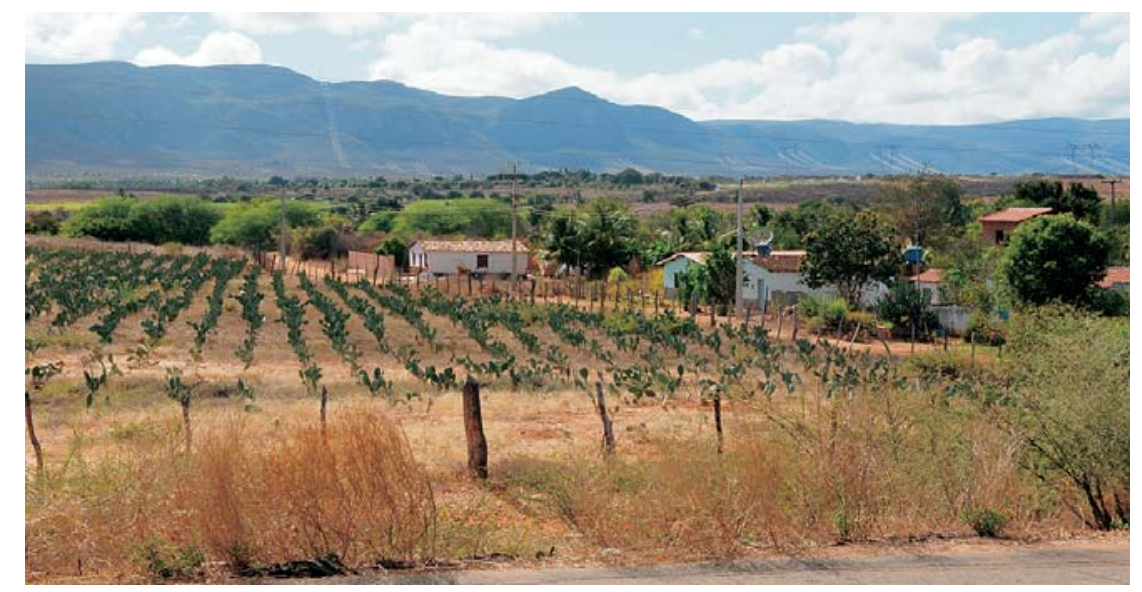




\section{Conclusions}

The landscape in the study area is dominated by two main peneplains, a higher surface and a lower surface that were both formed as low-relief erosion surfaces. The higher surface developed during the Cenozoic, probably during the Palaeogene as other similar plateaux in Brazil. The lower surface formed during the Neogene after the deposition of the Sabiá Formation and an uplift event that raised the higher surface to its present elevation around $1000 \mathrm{~m}$ a.s.l.

The uplift resulted in rejuvenation of the relief and subsequent formation of the lower surface. Progressive backward erosion along the main rivers has resulted in escarpments that separate the two surfaces. The escarpments are pronounced at geological boundaries with large differences of erosional resistance. Even the lower surface is presently under destruction due to minor subsequent uplift. In summary, we find that the passive margin topography in the study area was shaped many millions of years after the Early Cretaceous break-up of the South Atlantic. The conclusion that the landscape is mainly Cenozoic is thus in agreement with that of, e.g. King (1967). A better understanding of the timing of uplift events will be achieved from apatite fission-track data as well as the amount of exhumation involved in the formation of the erosion surfaces.

\section{Acknowledgements}

The study was funded by StatoilHydro do Brasil and Petrobras.

\section{References}

Bonow, J.M., Lidmar-Bergström, K. \& Japsen, P. 2006: Palaeosurfaces in central West Greenland as reference for identification of tectonic movements and estimation of erosion. Global and Planetary Change 50, 161-183.

Bonow, J.M., Japsen, P., Green, P.F., Wilson, R.W., Chalmers, J.A., Klint, K.E.S., van Gool, J.A.M., Lidmar-Bergström, K. \& Pedersen, A.K. 2007: A multi-disciplinary study of Phanerozoic landscape development in West Greenland. Geological Survey of Denmark and Greenland Bulletin 13, 33-36.

Cobbold, P.R., Meisling, K.E. \& Mount, V.S. 2001: Reactivation of an obliquely rifted margin, Campos and Santos basins, southeastern Brazil. American Association of Petroleum Geologists Bulletin 85, 1925-1944.
Cobbold, P.R., Marais-Gilchrist, G., Chiossi, D., Fonseca Chaves, F., Gomes de Souza, F. \& Lilletveit, R. 2008: Large submarine slides on a steep and narrow continental margin (Camamu Basin, NE Brazil). American Association of Petroleum Geologists Annual Convention, San Antonio, Texas, 20-23 April, 1 p.

CPRM-Geological Survey of Brazil 2001: Geological map of Brazil, 1:5000 000 (CD-ROM).

CPRM-Geological Survey of Brazil 2003: Geologia e Recursos Minerais do estado da Bahia 1:1000 000 (CD-ROM).

Davison, I. 1999: Tectonics and hydrocarbon distribution along the Brazilian South Atlantic margin. Geological Society, London, Special Publications 153, 133-151.

Gallagher, K., Hawkesworth, C.J. \& Mantovani, M.S.M. 1994: The denudation history of the onshore continental margin of SE Brazil inferred from apatite fission track data. Journal of Geophysical Research 99, $18117-18145$.

Japsen, P., Bonow, J.M., Green, P.F., Chalmers, J.A. \& Lidmar-Bergström, K. 2006. Elevated, passive continental margins: long-term highs or Neogene uplifts? New evidence from West Greenland. Earth and Planetary Science Letters 248, 315-324.

Japsen, P., Bonow, J.M., Green, P.F., Chalmers, J.A., \& Lidmar-Bergström, K. 2009: Formation, uplift and dissection of planation surfaces at passive continental margins. Earth Surface Processes and Landforms 34, 683-699.

Jarvis, A., Reuter, H. I., Nelson, A. \& Guevara, E. 2008: Hole-filled seamless SRTM data V4, International Centre for Tropical Agriculture (CIAT). Available from http://srtm.csi.cgiar.org.

King, L.C. 1967: The morphology of the Earth, 2nd edition, 699 pp. Edinburgh: Oliver and Boyd.

Lima, M. da Guia 2008: A história do intemperismo na província Borborema oriental, Nordeste do Brasil: Implicações paleoclimáticas e tectônicas, 251 pp. Unpublished Ph.D. thesis, Universidade Federal do Rio Grande do Norte, Brazil.

Magnavita, L.P., Davison, I. \& Kusznir, N.J. 1994: Rifting, erosion, and uplift history of the Recôncavo-Tucano-Jatobá Rift, northeast Brazil. Tectonics 13, 367-388.

Morais Neto, J.M., Green, P.F., Karner, G.D. \& Alkmim, F.F. in press: Age of the Serra do Martins Formation, Borborema Plateau, northeastern Brazil: constraints from apatite and zircon fission track analysis. Boletim de Geociências da Petrobras 16

Ollier, C.D. 1985: Morphotectonics of passive continental margins: introduction. Zeitschrift für Geomorphologie N.F., Suppl. 54, 1-9

Sant'Anna, L.G., Schorscher, H.D. \& Riccomini, C. 1997: Cenozoic tectonics of the Fonseca Basin region, eastern Quadrilátero Ferrífero, MG, Brazil. Journal of South American Earth Sciences 10, 275-284.

Spier, C.A., Vasconcelos, P.M. \& Oliviera, S.M.B. 2006: ${ }^{40} \mathrm{Ar} / 39 \mathrm{Ar}$ geochronological constraints on the evolution of lateritic iron deposits in the Quadrilátero Ferrífero, Minas Gerais, Brazil. Chemical Geology 234, 79-104

Viana, C.F., Gama Junior, E., Simões, I.A., Moura, J.A., Fonseca, J.R. \& Alves, R.J. 1971: Revisão estratigráfica da bacia Recôncavo/Tucano. Boletim Técnico da Petrobras 14, 157-192.

\footnotetext{
Authors' addresses

J.M.B \& P.J., Geological Survey of Denmark and Greenland, Øster Voldgade 10, DK-1350 Copenhagen K, Denmark. E-mail: jbon@geus.dk P.F.G., Geotrack International Pty Ltd, 37 Melville Road, Brunswick West 3055, Victoria, Australia.

P.R.C., Géosciences-Rennes (UMR6118 du CNRS), Université de Rennes, 35042 Rennes Cedex, France. A.J.P., Geological Survey of Brazil (CPRM), Avenida Ulysses Guimaraes, 2862, 41213-000 Salvador, Brazil.

R.L., StatoilHydro, Angola team, Stavanger, Norway.

D.C., StatoilHydro do Brazil, Rio de Janeiro, Brazil.
} 